\title{
Do Top Executives Determine Firm Risk and Stock Liquidity? Evidence from Selected BRICS Firms
}

\author{
KHURRAM IFTIKHAR BHATTI \\ PhD Scholar, COMSATS University, Islamabad, Pakistan \\ Email: khurrambhatti@live.com \\ MUHAMMAD IFTIKHAR UL HUSNAIN \\ COMSATS Institute of Information Technology Islamabad Pakistan \\ Email: iftikharhusnain@comsats.edu.pk \\ ABUBAKR SAEED \\ COMSATS Institute of Information Technology Islamabad, Pakistan \\ Email: abubakr.saeed@comsats.edu.pk
}

\begin{abstract}
The objective of the study is to investigate the role of observable and unobservable characteristics of top management team on firms' risk and stock liquidity. To examine this relationship, we have used managerfirm matched panel data from 2010 to 2018 of top non-financial listed companies of BRICS. Our result shows that managers' financial styles do have an influence on stock liquidity and firms' risk and that too differs from country to country and across different managers. Additionally, observable characteristics like gender, age, experience and qualification are also important to explain the manager financial styles. Based upon the findings we suggest that potential investors and Investment analysts should not only focus on quantitative analysis, but they should also consider the manager individual characteristics when evaluating any company.
\end{abstract}

Keywords: Manager Financial Styles, Stock Liquidity, Beta, Amivest, Observable Characteristics, BRICS.

\section{Introduction}

The purpose of the study is to investigate how top management team influence the decision making of the firm by considering the unobservable and observable characteristics on stock liquidity and firm's risk. The study focuses on the non-financial companies of BRICS ${ }^{1}$ and includes only those firms whose managers switched from one company to another during the sample. Empirically it has been evident that top manager does influence the key decisions of the company (Bertrand and Schoar, 2003 \& Kutan, Naz, \& Shah, 2018). Whereas, the literature is limited with respect to subject matter, economic and geographic context which our study has covered.

How much the top management team matter for firm behavior? In finance, economic and management literature; the top managers influence the firm financial decisions, policies and shareholder performance which has been the center of attention for many researchers from decades (Rotemberg \& Saloner, 2000; Van den Steen, 2004). In early literature, the studies were mainly focused on industry level, firm-level, and market-level characteristics and overlooked the importance of individual managers who play a crucial role in shaping these results.

${ }^{1}$ Brazil, Russia, India, China and South Africa. 
The top management team includes CEOs, CFOs and all other members who have the responsibility to make key decisions of the company (Wiersema \& Bantel, 1992). Different managers have a different way of working. As per Bertrand and Schoar (2003) managers are often regarded as having their own "styles" when they make any decision and these styles are imprinted on the company they manage. In earlier studies, these "styles" are also referred to as manager's financial style, manager fixed effects and idiosyncratic style (Bertrand \& Schoar, 2003; Dejong \& Ling, 2013; Kutan, Naz, \& Shah, 2018). Empirically it has been examined that top management team has different financial styles, so in continuation with the previous studies, we will study the impact of top managers by considering the observable and unobservable characteristics on stock liquidity and firm risk.

Stock liquidity is usually known as the difficulty of trading stock with the lowest cost, fastest speed and minimum price considering the market flexibility, depth, width, and proximity. Chordia, Subrahmanyam, and Anshuman (2001) explained in their study that stock liquidity is the integral factor of asset pricing which affects the expected rate of return, market efficiency, transaction costs, and overall financial stability. In previous studies, corporate stock liquidity has been investigated in the context of economic consequences. Several other studies concluded that stock liquidity affects stock returns (Acharya \& Pedersen, 2005; Amihud, 2002; Dongwei \& Yuanxun, 2004). Additionally, if there is more stock liquidity then it will increase the noise trading which ultimately increases the stock mispricing and corporate default risk (Polk \& Sapienza, 2008). It has already been proven that stock liquidity increases the company value, improve corporate governance and price efficiency (Dongwei \& Yuanxun, 2004; Polk \& Sapienza, 2008). Xiong (2016) investigated in their study that stock liquidity impacts the firm performance and agency cost through the mechanism of shareholder supervision, mechanism of management remuneration contract and mechanism of management opportunism. In the early 2000 Worldcom and Enron scandals are the eminent illustrations where the firms performed window dressing in the financial data to earn benefits. In relation to this, Edmans (2009) articulated in his study that sometimes top managers can take short term decisions to show the increase in the wealth of the shareholders. It has been evident from the previous researches that when there is conflict between shareholders and managers then the decisions taken in that particular period are not in the best interest of firm (Booth \& Schulz, 2004; Harrell \& Harrison, 1994; Harrison \& Harrell, 1993; Rutledge \& Karim, 1999; Tuttle, Harrell, \& Harrison, 1997). Y. Chen, Rhee, Veeraraghavan, and Zolotoy (2015) investigated in their studies that stock liquidity alleviates the short-term decision behavior in corporate earning management. Whereas, Jiang, Ma, and Shi (2017) investigated that companies where the information transparency is low will have more conflicts of interest between shareholders and managers.

Since the companies are exposed to risks on daily basis, hence it is essential to respond to these in timely and effective manner. Here the management plays a vital role in exploring the different types of risk and designing appropriate strategies to cater them. The risk might not be negative each time. At times firms themselves make risky strategic choices to explore new markets. This is driven by increased competition, globalization, innovation and a constant need to search new avenues. Since it is the managers taking all the decisions, therefore their characteristics might strongly impact their decision making which this study aims to explore (Gustafsson \& Uysal, 2018). A firm's risk-taking ability can also be influenced by its political connections. According to Goldman, Rocholl, and So (2009) the political connections are generally associated with a lot of non-value maximizing activities which in turn can obstruct the growth of the firm. Hence there are various ways to measure firm's risk, our study uses beta as a measure of risk as discussed in methodology section.

Various observable characteristics such as age, education, gender and experience etc. have been used in many researches (Chernin, 2008; Das, 2014). The primary theory which supports the observable characteristics in organizational decisions is Upper echelon theory (UET) presented by Hambrick and Mason (1984). It has been empirically evident that company's performance is somewhat influenced by the managers characteristics like principles and experience (Smith \& White, 1987; Thomas, Litschert, \& Ramaswamy, 1991; Tihanyi, Ellstrand, Daily, \& Dalton, 2000). The upper echelon theory proposed that 
manager personal characteristics can influence directly to the decision-making process. Many studies are in line with the proposition of UET like Perryman, Fernando, and Tripathy (2016). They concluded that gender diversity in top management team will tend to reduce the risk and enhance the company's performance. Moreover, Vroom and Pahl (1971) studied the association between firm risk-taking behavior and manager's age. They summed up their results that older managers will tend to take lower risks due to their family commitments and obligations as compared to young managers. Many studies believe that risk is an appropriate measure to gauge the top management team observable characteristics like R\&D expenditure (Elsaid \& Ursel, 2011b), leverage (Faccio, Marchica, \& Mura, 2016), stock return volatility (Cassell, Huang, Sanchez, \& Stuart, 2012; Khan \& Vieito, 2013; Kini \& Williams, 2012; M. A. Serfling, 2014) and cash holdings (Bernile, Bhagwat, \& Rau, 2017; Elsaid \& Ursel, 2011a).

Our study is mainly focused on emerging economies like BRICS (Brazil, Russia, India, China and South Africa). All these five countries have significant influence on global and regional affairs. Additionally, a study revealed that these five countries represents $40 \%$ of the world population and approximately covers $20 \%$ of the world GDP (Tripathi \& Kumar, 2014). A renowned economist Glodman Sachs predicted regarding BRICS economies that it would outperform before the middle of the century (Glosny, 2010). The reason to choose BRICS countries is that these are considered as newly industrialized, emerging and fast developing economies (Pedro, Irene, Doris, \& Thobias, 2012). Previous studies show that BRICS have become a challenging economic force globally by expanding trade with the rest of the world (LalthapersadPillay, 2014). In continuation to Kutan et al. (2018) and Bertrand and Schoar (2003), our study contributes in three-fold, subject matter, economic and geographic context. It has been observed that most of the manager's characteristic studies have been conducted on developing and developed countries and very little attention was given to emerging economy which contributes a major part of the world economy. Another reason to choose BRICS is because all the countries are different in terms of their financial structures, income level, technological advancement and political situations, so it is required to have a different geographic and economic context in order to commend any financial and economic concept. Furthermore, the prevailing literature overlooked the manager financial styles on stock liquidity and firm risk (which is a limitation with respect to subject matter). Since the top management team is the one which is directly involved in the financial decision making so they clearly matter. With respect to business conduct, this study mainly focused on non-financial companies of BRICS listed on their respected stock exchanges. The non-financial firms are the major contributors to the economy, so we chose the top 100 firms. Financial firms have quite different standards and accounting practices as compared to non-financial firms and they also have very strict regulations to be followed which ultimately reduces or disregards the effect of top management characteristics (Kutan et al., 2018). Henceforward, our study will explain how top management team stimulate the financial decisions of non-financial firms of BRICS with respect to stock liquidity and firm risk.

Additionally, our study will create value for the regulatory authorities and stakeholders who will thoroughly analyze the financial figures because they know that top management team's characteristics will influence stock liquidity and firm's risk. This study will help the potential investors who can easily foresee the security of their investment by knowing the top management team's financial decisions.

\section{Literature Review}

According to neoclassical theory all the managers are same and perfect substitute of each other. Henceforth, it will limit the different financial styles of managers and their impact on corporate outcomes (Weintraub, 2007). Whereas, Bertrand and Schoar (2003) provided a different view that firm's fixed effect and manager's fixed effect are different and as per their findings managers have strong impact on firms financial decision. There are diverse decision-making theories developed in different time frames which are categorized into four different parts. Normative theory (1950s), Descriptive theory and Agency theory (1970s) and Upper Echelon (1980s). Normative theory supported the view that humans take decisions on well-defined parameters or as per ideal scenario without incorporating the cognitive part. This theory lacks 
the subjectivity element, so to fulfil the cognitive element descriptive theory was introduced. The descriptive theory states that decisions taken by the humans contains irrationality and biases issues, that's why every decision taken by the managers are different. After the neoclassical view, the classical strategic management shared a new perspective when upper echelon theory (UET) developed (Hambrick \& Mason, 1984). The Upper echelon theory provided the concept of bounded rationality, that current decisions are taken on the basis of past experiences (Finkelstein, Hambrick, \& Cannella, 1996; Hambrick, 2007; Hambrick \& Mason, 1984). There are number of studies on upper echelon theory which supports that many factors such as tenure and age (Herrmann \& Datta, 2005) and education (Tihanyi et al., 2000) can be characteristics of top managers cognitive abilities. Another very important aspect is the relationship between principal and agent which is covered by the agency theory. The shareholders (principal) delegate the work to manager (agent) with an anticipation that manager will work in the best interest of company (Meckling \& Jensen, 1976). Beaudoin (2008) concluded in his study that both manager and shareholder have good relationship with each other, but they do have different risk-taking attitudes. hence, these theories are in line with our research that there is some relationship between top manager's financial styles, firm risk and stock liquidity.

Glover and Levine (2015) investigated that managers impact significantly on firm risk because they take higher risk in order to get higher, yet volatile returns. These volatile risks ultimately affect the forecasting and planning of the company's cash flows and firm policies (Bloom \& Milkovich, 1998). In finance theories, corporate firm behavior was described as traditional firm model. Manager compensation and motivation is the area where very little attention was paid, which are the key elements of business continuity. Hence, their decisions must be in line with the shareholders' interest (Kutan et al., 2018). A study conducted by Singh and Harianto (1989), investigated that managerial ownership plays a vital role in firm's risk. If the managers do not have large shares then they will opt risky projects in order to get higher returns, which are in the interest of all investors. But some evidence shows that few managers are risk averse and do not take risky project although those risky projects may increase the value of the firm (Hirshleifer \& Thakor, 1992). However, Sappington (1991) concluded in their study that managers who are less risky will get more incentives due to information asymmetry for putting less efforts. To cope up with this issue shareholders will adopt some monitoring tool to foresee the managers' interest (Sappington, 1991;Arnold \& De Lange, 2004)

H1: Top management team financial styles are anticipated to have a relationship with firm risk.

Few researchers investigated that stock liquidity inversely impacts the risk-taking decisions. Because higher stock liquidity will augment the information content of stock prices such as decrease in cost of capital and transaction cost. The firm takes strategic decisions based upon the comparison of risk and return (Bolton, Chen, \& Wang, 2011; Copeland, Koller, \& Murrin, 2002). Furthermore, if the cost of capital for a project decreases then it will create comfort in firms' financial constraints which will eventually allow the manager to invest in risker projects (Bruno \& Shin, 2015; Edmans, Fang, \& Zur, 2013; Paligorova \& Santos, 2017). Bruno and Shin (2015) explained that increase in liquidity will reduce the financial restraints of firm which will ultimately encourage top managers to take riskier decisions in order to get the managerial compensation. In contrast to this, some studies show that higher stock liquidity may discourage risk-taking because it increases the chances of hostile takeover (Fang, Tian, \& Tice, 2014), which ultimately increase the managerial biasness towards long term risky projects. For example innovative projects or investment in R\&D (H. L. Chen, Ho, \& Hsu, 2013). Y. Chen et al. (2015) examined that higher stock liquidity will increase the pressure on top managers from the capital market to take short term decisions. They also concluded in their study that firms with higher pay-for-performance sensitivity have strong relationship with stock liquidity and earning management.

H2: Top management team financial styles are anticipated to have a relationship with stock liquidity. 
According to the literature, the observable characteristics (e.g.; gender, age, experience and education) of top management team impacts the firm's risk and stock liquidity. Sundaram and Yermack (2007) and Hambrick and Mason (1984) explored that older managers are more conservative in decision making because they are more concerned about future financial securities rather than taking risky business projects. Regarding the education of top management team, literature shows mixed results between MBA education and risk-taking attitude (Chevalier \& Ellison, 1999; Graham, Harvey, \& Puri, 2013). Gender diversity explains different results such as women take less risky decisions as compared to men. Literature also suggests that the gender structure of the board will impact the stock liquidity (Ahmed \& Ali, 2017).

H3: Observable characteristics of the top management team have a significant impact on firm risk and stock liquidity.

\section{Empirical Model}

In continuation with the study conducted by Kutan et al. (2018), they used the model proposed by Bertrand and Schoar (2003) to study the impact of manager's financial styles on stock liquidity and firm's risk. Below is the equation used to examine our research objectives.

$$
\begin{gathered}
y_{i t}=\alpha_{t}+\gamma_{i}+\beta X_{i t}+\epsilon_{i t} \\
y_{i t}=\alpha_{t}+\gamma_{i}+\beta X_{i t}+\lambda_{C E O}+\mu_{C F O}+\eta_{o t h e r s}+\epsilon_{i t}
\end{gathered}
$$

In the above equation $y_{i t}$ represents the stock liquidity and firm risk in each year, $\alpha_{t}$ denoted as year fixed effect, $\gamma_{i}$ represents the firm fixed effect, $\mathrm{X}_{\mathrm{it}}$ is the vector of time-varying firm level characteristics and $\epsilon_{\mathrm{it}}$ is denoted as error term. The variables such as $\lambda_{\text {CEO, }} \mu_{C F O}$ and $\eta_{\text {others }}$ are explained as incremental fixed effect of every manager with respect to firms' risk and stock liquidity. Additionally, $\lambda_{\text {CEO, }}$ is denoted as fixed effect of managers being CEOs in the earlier position, $\mu_{C F O}$ symbolizes as CFO fixed effect who were former $\mathrm{CFO}$ and $\eta_{\text {others }}$ denoted as manager fixed effect who were other than $\mathrm{CEO}$ and $\mathrm{CFO}$ in previous positions.

Equation 1 is the benchmark which includes all the firm-level control variables, firm and time fixed effect that permits us to investigate the variation in dependent variable. While, equation 2 includes CEO, CFO and other top management team to observe their part in explaining the stock liquidity and firm's risk. However, it is obvious that equation 1 cannot estimate the manager fixed effect because the manager has not switched the company during the sample period. And maybe he has been promoted from CFO to CEO position within the same firm, but the fixed effect of that manager cannot be investigated on corporate practices. So, based upon the methodology used by Bertrand and Schoar (2003), we incorporate only those managers in our sample who moved from one company to another over the period of our study. The minimum duration to stay in one firm is three years. Those managers who did not move from one firm to another will be excluded from our sample because both the firm and managers fixed effects are co-linear.

\section{Construction of Sample}

The sample of our study is based upon the longitudinal design ${ }^{2}$ to track the managers financial styles used by (Bertrand \& Schoar, 2003; Kutan et al., 2018). The sample consists of top 100 non-financial companies of BRICS based upon their market capitalization listed on their respective stock exchanges. All the financial institutions such as banks and insurance companies are excluded from the sample. Data of nonfinancial firms were gathered from DataStream and GuruFocus. Top managers data has been taken from "Who's who and who was who" from 2010 to 2018 period. Moreover, only those companies were included in the sample where the managers have served a minimum of three years, and if the top managers move to

${ }^{2}$ A longitudinal study consists of observations which are gathered for the same subject repeatedly over the period. 
new company then sample has been extended accordingly. But if the manager moved to any financial company then those companies were excluded from the sample. In this study we have used observable characteristics like age, gender, experience and education to test our hypothesis. The education and gender are dummy variables. For example, ' 1 ' for $\mathrm{MBA}$ and ' 1 ' for male and ' 0 ' otherwise for respective variables. Moreover, we use 'Age' to show the age of the top managers and lastly 'experience' is termed as the number of years top manager works in an office.

\section{Estimation Techniques}

To analyze the panel data, normally there are two techniques that are used (i) random effect and (ii) fixed effect. In random effect model the variation across entities is expected to be uncorrelated with independent variable. The advantage of random effect model is that you can incorporate the time invariant characteristics and it needs to be highlighted to those individual characteristics which may or may not influence the independent variable. However, the fixed effect model explains all the time invariant differences between the individual characteristics such as age, race, gender and religion etc. Practically, fixed effect models are intended to investigate the various reasons for changes in a person for an entity. Since the time invariant characteristic is constant for every individual, therefore it cannot cause such a change. We used Hausman test to confirm which model will serve the purpose. Hence, fixed effect model is used to conclude the results.

\section{Measurement of Variables}

Amivest the measure of liquidity is presented by Cooper, Groth, and Avera (1985) which is calculated as the ratio of trading volume and absolute return. The amivest measure can be calculated as:

$$
\text { 20. AMIVEST }=\frac{1}{T} \sum_{t=1}^{T} \frac{\mid \text { ShareVolume } \mid}{\left|r_{t}\right|} e_{t}
$$

However, $\mathrm{T}$ is denoted as the days with zero returns. Where, |Share Volume| is represented as trading volume of stock and $\left|r_{t}\right|$ is the absolute return of stock on day t. Majority of the earlier studies have used the Amivest as a measure of liquidity and some used Amihud which is the inverse of Amivest for example (Acharya \& Pedersen, 2005; Amihud, 2002; Cooper et al., 1985; Datar, Naik, \& Radcliffe, 1998; Haugen \& Baker, 1996; Kamara, Lou, \& Sadka, 2008; Khan \& Baker, 1993; Marcelo \& Quirós, 2006; Rouwenhorst, 1999).

There are many other liquidity measures, but this one has two main advantages. Firstly, it has simple construction to capture the price impact as it uses absolute value of the daily return to volume ratio. Secondly, it has significant positive association with anticipated stock return (Amihud, 2002; Chordia, Huh, \& Subrahmanyam, 2009; Jiang et al., 2017). In this paper, to measure the stock liquidity we use annual variation of this indicator. The stock liquidity $\left(\mathrm{CAMH}_{i, t}\right)$ will be expressed as annual variation of $\mathrm{AMH}_{i, t}$. We have incorporated control variables such as size (log of firm total asset), stock price ( $p r c$ ), cash balance divided by total asset of firm $(\mathrm{C} b)$. The motive of the investors is to earn systematic risk premium, so they are focused towards the systematic risk. According to the study of Albuquerque, Koskinen, and Zhang (2019), they used Beta coefficient value of stock $i$ in year $t$ to quantify the level of systematic risk of stock $i$ in year $t$. The equation of this measure is as follows:

$$
\operatorname{Ret}_{i, t, d}=\beta_{0}+\operatorname{Beta}_{i, t} * \mathrm{M} \operatorname{Ret}_{i, t, d}+\varepsilon_{i, t, d}
$$

Where Ret $_{\mathrm{i}, \mathrm{t}, \mathrm{d}}$ is referred as return of stock $i$ and MRet $_{\mathrm{t}, \mathrm{d}}$ is termed as market of share on dth trading day in year $t$. Considering the daily return of stock $i$ and market of share in year $t$, Beta $_{\mathrm{i}, \mathrm{t}}$ is projected and then the annual corporate market risk of stock $i$ in time $t$ can be calculated. We incorporated control variables such as size, capital expenditure, operating cash flow, net-working capital and market to book ratio. 


\section{Analysis}

Descriptive statistics have been portrayed in Table 1 for all the sample companies of Brazil, Russia, India, China and South Africa. The table shows the mean, median and standard deviation of all the variables used in this study.

Table1 Country-wise non-financial firms characteristics summary

\begin{tabular}{|c|c|c|c|c|c|c|c|c|c|c|}
\hline \multicolumn{11}{|c|}{ Sample of Manager-Firm Matched Data } \\
\hline Country & $\begin{array}{c}\text { Descriptive } \\
\text { Stats }\end{array}$ & $\begin{array}{c}\text { Capital } \\
\text { Expenditure }\end{array}$ & Size & $\begin{array}{l}\text { Stock } \\
\text { Price }\end{array}$ & $\begin{array}{c}\text { Operating } \\
\text { Cash } \\
\text { Flows } \\
\end{array}$ & $\begin{array}{c}\text { Net } \\
\text { Working } \\
\text { Capital } \\
\end{array}$ & $\begin{array}{c}\text { Cash } \\
\text { Balance }\end{array}$ & Beta & $\begin{array}{c}\text { Stock } \\
\text { Liquidity }\end{array}$ & $\begin{array}{c}\text { Sample } \\
\text { Size }\end{array}$ \\
\hline \multirow{7}{*}{ 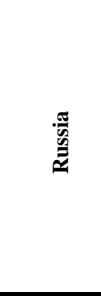 } & Mean & $(0.20)$ & 11.59 & 184.54 & 0.19 & 0.14 & 0.18 & 0.017 & 17.91 & \\
\hline & Median & $(0.07)$ & 11.49 & 36.26 & 0.09 & 0.10 & 0.07 & 0.018 & 18.53 & \\
\hline & St. Dev. & 2.53 & 1.98 & 481.01 & 4.15 & 0.47 & 2.20 & 0.107 & 3.07 & \\
\hline & $\mathrm{p} 25$ & $(0.12)$ & 10.26 & 13.66 & 0.04 & 0.02 & 0.04 & 0.009 & 15.87 & \\
\hline & p75 & $(0.03)$ & 12.69 & 136.24 & 0.13 & 0.21 & 0.13 & 0.032 & 19.58 & \\
\hline & Min & $(71.33)$ & 4.33 & 0.32 & $(31.50)$ & $(0.70)$ & 0.00 & $(0.777)$ & 11.35 & \\
\hline & $\operatorname{Max}$ & - & 16.81 & $4,956.85$ & 114.17 & 11.24 & 62.75 & 0.410 & 26.23 & \\
\hline \multirow{7}{*}{ ตี } & Mean & $(0.17)$ & 10.28 & 50.53 & 0.11 & 0.70 & 0.64 & 0.011 & 13.55 & \\
\hline & Median & $(0.06)$ & 10.18 & 14.40 & 0.08 & 0.10 & 0.09 & 0.011 & 13.43 & \\
\hline & St. Dev. & 1.60 & 1.76 & 255.89 & 4.75 & 12.03 & 8.34 & 0.084 & 2.66 & \\
\hline & p25 & $(0.09)$ & 9.36 & 7.51 & 0.04 & 0.00 & 0.04 & 0.005 & 6.39 & \\
\hline & p75 & $(0.02)$ & 11.04 & 27.08 & 0.13 & 0.22 & 0.17 & 0.020 & 25.87 & \\
\hline & Min & $(40.00)$ & 2.08 & 1.24 & $(80.25)$ & $(8.79)$ & $(0.01)$ & $(0.567)$ & 8.44 & \\
\hline & Max & 0.14 & 15.77 & $3,545.50$ & 89.30 & 299.00 & 178.25 & 0.217 & 20.13 & \\
\hline \multirow{7}{*}{ 氖 } & Mean & $(0.07)$ & 10.19 & 1.82 & 0.12 & 0.09 & 0.11 & 0.003 & 20.30 & \\
\hline & Median & $(0.05)$ & 10.13 & 1.00 & 0.10 & 0.09 & 0.09 & 0.004 & 20.20 & \\
\hline & St. Dev. & 0.06 & 1.81 & 10.17 & 0.13 & 0.21 & 0.08 & 0.081 & 1.31 & \\
\hline & $\mathrm{p} 25$ & $(0.10)$ & 9.15 & 0.82 & 0.05 & $(0.01)$ & 0.06 & 0.000 & 19.50 & F \\
\hline & $\mathrm{p} 75$ & $(0.03)$ & 11.10 & 1.30 & 1.15 & 0.20 & 0.16 & 0.000 & 20.90 & \\
\hline & Min & $(0.30)$ & 5.87 & 0.00 & $(0.35)$ & $(0.49)$ & 0.01 & $(0.294)$ & 17.00 & \\
\hline & $\operatorname{Max}$ & 0.01 & 14.40 & 164.25 & 0.75 & 0.71 & 0.50 & 0.227 & 23.90 & \\
\hline \multirow{7}{*}{ : } & Mean & $(0.07)$ & 12.24 & 393.34 & 0.12 & 0.12 & 0.05 & 0.011 & 19.71 & \\
\hline & Median & $(0.07)$ & 12.28 & 165.29 & 0.10 & 0.07 & 0.03 & 0.016 & 20.16 & \\
\hline & St. Dev. & 0.06 & 1.77 & 601.31 & 0.12 & 0.21 & 0.07 & 0.074 & 1.74 & \\
\hline & $\mathrm{p} 25$ & $(0.10)$ & 11.15 & 73.26 & 0.05 & $(0.05)$ & 0.01 & 0.005 & 18.67 & \\
\hline & p75 & $(0.04)$ & 13.59 & 413.00 & 0.16 & 0.24 & 0.08 & 0.042 & 21.03 & \\
\hline & Min & $(0.54)$ & 7.04 & 1.52 & $(0.35)$ & $(0.26)$ & - & $(0.473)$ & 15.60 & \\
\hline & Max & 0.14 & 15.92 & $3,545.50$ & 0.80 & 0.89 & 0.05 & 0.219 & 26.60 & \\
\hline \multirow{7}{*}{ 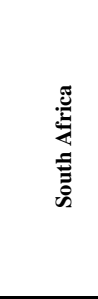 } & Mean & $(0.05)$ & 10.42 & 1.07 & 0.09 & 0.17 & 0.11 & 0.009 & 18.31 & \\
\hline & Median & $(0.04)$ & 10.47 & 1.10 & 0.09 & 0.10 & 0.09 & 0.017 & 18.97 & \\
\hline & St. Dev. & 0.04 & 1.84 & 0.36 & 0.05 & 0.17 & 0.07 & 0.055 & 1.68 & \\
\hline & $\mathrm{p} 25$ & $(0.07)$ & 9.57 & 0.91 & 0.05 & 0.04 & 0.07 & 0.007 & 16.77 & \\
\hline & p75 & $(0.03)$ & 11.39 & 1.31 & 0.12 & 0.23 & 0.13 & 0.039 & 19.50 & \\
\hline & Min & $(0.18)$ & 6.05 & 0.08 & $(0.05)$ & $(0.04)$ & - & $(0.302)$ & 14.52 & \\
\hline & $\operatorname{Max}$ & - & 14.79 & 1.80 & 0.28 & 0.55 & 0.33 & 0.155 & 21.21 & \\
\hline
\end{tabular}

Notes: Descriptive statistics run on STATA 
The data consists of all non-financial companies of BRICS for which the descriptive statistics demonstrate the difference between $\max$ and min value. So, the results show that stock market liquidity fluctuate significantly ranging from 11.35 to $26.23 ; 8.44$ to $20.13 ; 17.00$ to $23.90 ; 15.60$ and $26.60 \& 14.52$ to 21.21 with mean (median) of 17.91 (18.53); 13.55 (13.43); 20.13 (20.20); 19.71 (20.16) \& 18.31 (18.97) for Russia, Brazil, China, India and South Africa respectively. Further examination discovered that stock liquidity (measured through Amivest) of the sample companies have both low and high stock liquidity. Additionally, statistical summary of firm risk (measured through Beta) varies differently from country to country. The range varies from $(0.77)$ to $0.41 ;(0.56)$ to $0.21 ;(0.29)$ to $0.22 ;(0.47$ to $0.21 \&(0.32)$ to 0.15 with mean (median) of $0.017(0.018) ; 0.011(0.011) ; 0.003(0.004) ; 0.011(0.016) \& 0.009(0.0017)$ which may vary from country to country and may be due to different risk preferences over different sectors and industry needs. Normally, stock which has higher beta value will tend to have more risk as compared to the stock which has lower beta. But this does not mean that stock which have negative beta contains no inherent risks. Furthermore, the average size of the company of aforementioned countries are 11.59, 10.28, $10.19,12.24 \& 10.42$ with minimum (maximum) values of 4.33 (16.81); 2.08 (15.77); 5.87 (14.40); 7.04 (15.92) \& 6.05 (14.79). To eliminate the problem of outlier we have winsorized all the variable at $1 \%$ (Kutan et al., 2018).

Table 2 Manager fixed effects on stock liquidity and firm's risk

\begin{tabular}{|c|c|c|c|c|c|}
\hline \multicolumn{6}{|c|}{ F-Test on fixed effect for } \\
\hline \multicolumn{2}{|r|}{$\mathrm{NO}$} & CEO & CFO & Others & Adjusted $\mathbf{R}^{2}$ \\
\hline \multirow{8}{*}{ 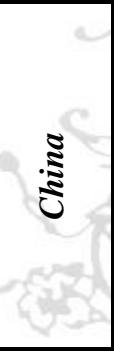 } & \multirow{4}{*}{ Risk } & & & & 0.509 \\
\hline & & $1.93(0.023)$ & & & 0.536 \\
\hline & & $2.40(0.000)$ & & & 0.768 \\
\hline & & $3.13(0.000)$ & $2.10(0.016)$ & $4.07(0.000)$ & 0.796 \\
\hline & \multirow{4}{*}{ Stock Liquidity } & & & & 0.060 \\
\hline & & $2.88(0.001)$ & & & 0.136 \\
\hline & & $6.05(0.000)$ & & & 0.401 \\
\hline & & $3.54(0.000)$ & $2.69(0.003)$ & $1.63(0.105)$ & 0.172 \\
\hline \multicolumn{2}{|r|}{ Sample Size } & \multicolumn{4}{|c|}{936} \\
\hline \multirow{8}{*}{$\underset{\Sigma}{\mathbb{Z}}$} & \multirow{4}{*}{ Risk } & & & & 0.738 \\
\hline & & $2.25(0.002)$ & & & 0.754 \\
\hline & & $3.49(0.000)$ & & & 0.783 \\
\hline & & $3.17(0.000)$ & $3.92(0.000)$ & $2.03(0.021)$ & 0.792 \\
\hline & \multirow{4}{*}{ Stock Liquidity } & & & & 0.315 \\
\hline & & $3.20(0.001)$ & & & 0.359 \\
\hline & & $1.49(0.065)$ & & & 0.404 \\
\hline & & $1.83(0.003)$ & $0.11(0.003)$ & $0.15(0.859)$ & 0.112 \\
\hline \multicolumn{2}{|r|}{ Sample Size } & \multicolumn{4}{|c|}{990} \\
\hline \multirow{8}{*}{ : } & \multirow{5}{*}{ Risk } & & & & 0.615 \\
\hline & & $2.09(0.056)$ & & & 0.627 \\
\hline & & $1.94(0.024)$ & & & 0.638 \\
\hline & & $3.31(0.000)$ & $1.78(0.083)$ & $4.42(0.000)$ & 0.703 \\
\hline & & & & & 0.712 \\
\hline & \multirow{3}{*}{ Stock Liquidity } & $3.91(0.001)$ & & & 0.734 \\
\hline & & $2.08(0.014)$ & & & 0.782 \\
\hline & & $3.58(0.000)$ & $4.74(0.000)$ & $0.75(0.6515)$ & 0.732 \\
\hline
\end{tabular}




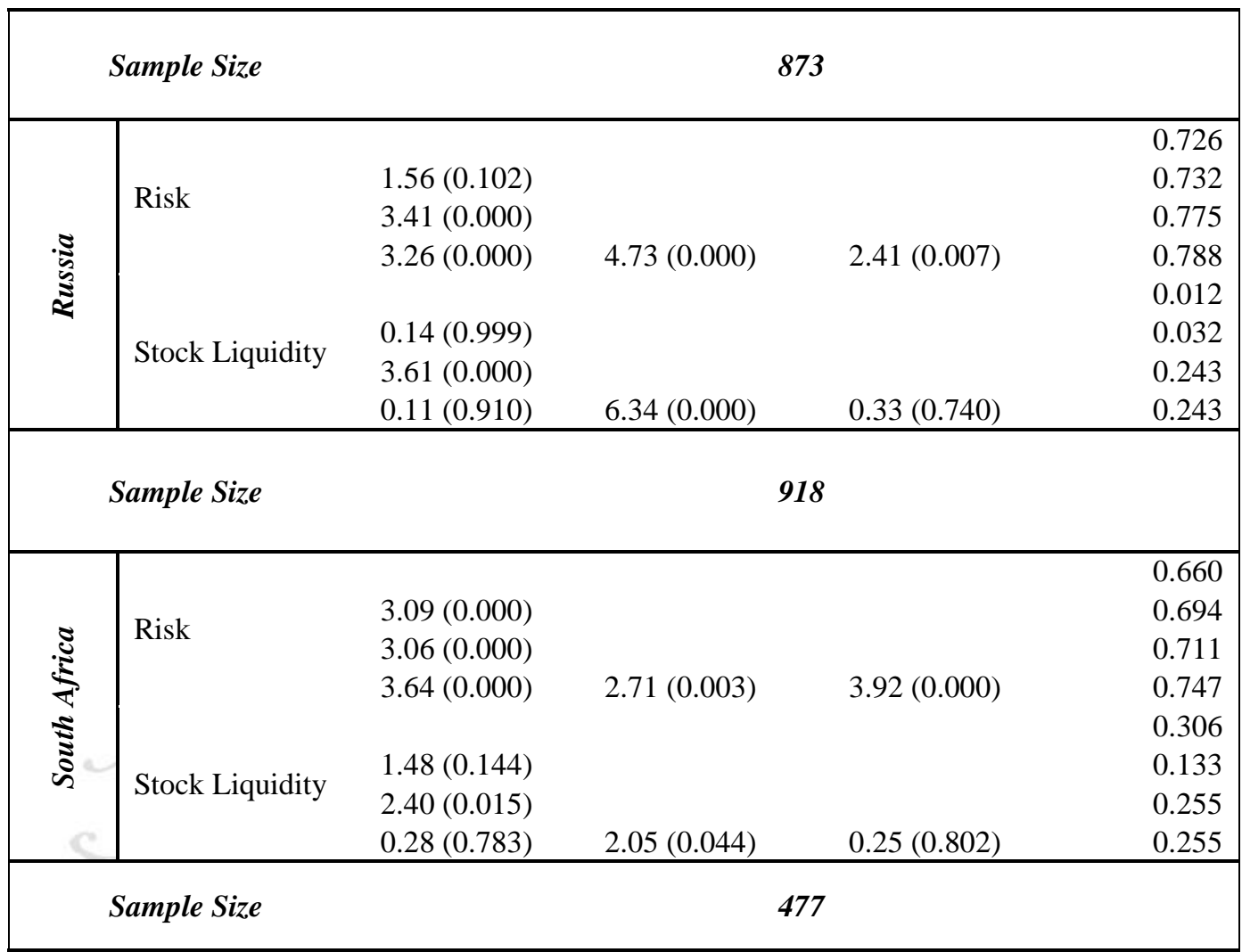

Notes: Sample is manager-firm matched panel data. Table shows the results of fixed-effect panel regression, whereas standard errors are gathered at firm level. The firm-fixed effects for each dependent variable (as stated in column) are; row 1: year fixed effect and firm fixed effect, row 2: year, firm and CEO-fixed effect, row 3: year, firm, CFO and CEO fixed effect; and row 4: year, firm and all manager-fixed effect. For each F-test we report the value of F-statistic and pvalue (mentioned in parentheses).

Table 3 Observable managerial characteristics on stock liquidity and firm's risk

\begin{tabular}{|c|c|c|c|c|c|c|c|c|c|c|c|}
\hline \multirow[b]{2}{*}{ Variables } & \multirow{2}{*}{$\begin{array}{c}\text { Observable } \\
\text { Characteristics }\end{array}$} & \multicolumn{2}{|c|}{ China } & \multicolumn{2}{|c|}{ India } & \multicolumn{2}{|c|}{ Russia } & \multicolumn{2}{|c|}{ Brazil } & \multicolumn{2}{|c|}{ South Africa } \\
\hline & & $\beta$ & $\begin{array}{c}\mathbf{P} \\
\text { Value }\end{array}$ & $\boldsymbol{\beta}$ & $\begin{array}{c}\mathbf{P} \\
\text { Value }\end{array}$ & $\beta$ & $\begin{array}{c}\mathbf{P} \\
\text { Value }\end{array}$ & $\boldsymbol{\beta}$ & $\begin{array}{c}\mathbf{P} \\
\text { Value }\end{array}$ & $\boldsymbol{\beta}$ & $\begin{array}{c}\mathbf{P} \\
\text { Value } \\
\end{array}$ \\
\hline \multirow{4}{*}{ Firm Risk } & Age & $(0.00)$ & 0.00 & -0.87 & 0.00 & $(0.00)$ & 0.00 & -0.08 & 0.05 & $(0.00)$ & 0.04 \\
\hline & Gender & 0.00 & 0.00 & 0.68 & 0.00 & 0.09 & 0.02 & 0.14 & 0.00 & 0.08 & 0.00 \\
\hline & Experience & 0.00 & 0.01 & 0.21 & 0.00 & 0.00 & 0.03 & 0.00 & 0.04 & 0.11 & 0.00 \\
\hline & Qualification & $(0.00)$ & 0.00 & -0.92 & 0.00 & -0.02 & 0.03 & -0.01 & 0.00 & -0.08 & 0.00 \\
\hline \multirow{4}{*}{$\begin{array}{c}\text { Stock } \\
\text { Liquidity }\end{array}$} & Age & -0.09 & 0.00 & -0.08 & 0.05 & -0.02 & 0.03 & -0.04 & 0.00 & -0.40 & 0.00 \\
\hline & Gender & 0.11 & 0.02 & 0.85 & 0.00 & 0.94 & 0.00 & 0.08 & 0.04 & 2.05 & 0.00 \\
\hline & Experience & 0.07 & 0.05 & 0.52 & 0.03 & 0.03 & 0.05 & 0.03 & 0.06 & 0.65 & 0.07 \\
\hline & Qualification & 0.32 & 0.05 & 1.46 & 0.02 & 0.65 & 0.07 & 0.71 & 0.01 & 0.59 & 0.00 \\
\hline \multicolumn{2}{|c|}{ Sample } & \multicolumn{2}{|c|}{936} & \multicolumn{2}{|c|}{990} & \multicolumn{2}{|c|}{918} & \multicolumn{2}{|c|}{873} & \multicolumn{2}{|c|}{477} \\
\hline
\end{tabular}

Note: Table shows individual manager observable characteristics. The sample consists of firm-year observation for which we gathered the information of dummy variable like age ( 1 for manager above 50 and 0 otherwise), gender ( 1 for male and 0 otherwise), experience ( 1 for 20 or more and 0 otherwise) and qualification ( 1 for MBA and 0 otherwise). Column 3,5,7,9 and 11 shows the estimated coefficient value of dummy variable for top management team and same is the case for $p$ value. 


\section{Discussion}

In table 2 study have reported the results of adjusted $\mathrm{R}^{2}$ and $F$ - tests from the estimation equation 2 for manager decisions on stock liquidity and firm risk. In benchmark measurement which represents time varying control variables, year fixed effect and firm fixed effect, we have reported for each variable in the first row. In the second row we have incorporated CEO fixed effect and then same process repeated for the third and fourth rows where we add CFO fixed effect and others fixed effect for the reporting of change in adjusted $\mathrm{R}^{2}$. In the third and fourth rows we add CFO and others with CEO in order to report $F$-statistics from the joint significance test of different sets of manager fixed effects.

The study reveals that top management team have both; a statistical and economic impact on firm's risk and stock liquidity. A significant increase is observed in the adjusted $\mathrm{R}^{2}$ of the estimated models by CEOs as well as other managers' fixed effects. Correspondingly, in maximum cases the $F$-tests allow us to reject the null hypothesis that all manager fixed effects are zero. The test results also depict those variables which are most affected by the top manager decisions. However, different types of decisions are influenced by different types of managers; e.g., CFOs have more impact on financial decisions (Bertrand \& Schoar, 2003). Further details of the test results are discussed below.

In Table 2 we have reported firm risk and stock liquidity. Let's take firm risk as a start of our results discussion. The results show that there is an increasing trend in adjusted $\mathrm{R}^{2}$ from the benchmark equation in each country. In China, the adjusted $\mathrm{R}^{2}$ of the benchmark equation is 0.509 and when we add CEO in the equation then it becomes 0.536; after incorporating CFO and others in the equation the adjusted $\mathrm{R}^{2}$ increased by 0.768 and 0.796 respectively. This incremental difference shows that managers do matter in firm risk decisions. In India, the adjusted $\mathrm{R}^{2}$ of the benchmark equation is 0.738 and after incorporating the CEO, CFO and others in the equation the adjusted $\mathrm{R}^{2}$ will increased by $0.754,0.783$ and 0.792 which clearly depicts that manager matters. Our study observes that CFO matters more as compared to the CEO; their presence express very significant impact on adjusted $\mathrm{R}^{2}$. Chava and Purnanandam (2007) are in line with our study that CEOs and CFOs are more exposed to risk. In Brazil, the adjusted $\mathrm{R}^{2}$ shows incremental trend. The benchmark equation shows 0.615 adjusted $\mathrm{R}^{2}$ and after incorporating CEO, CFO and others it will increased by $0.627,0.638$ and 0,703 respectively. The results of Russia and South Africa are also in line with the previous literature that manager matters for the firm risk-taking decisions. Empirically it has been confirmed that managerial incentive can encourage the top management team to take risky decisions (Armstrong, Larcker, Ormazabal, \& Taylor, 2013; Armstrong \& Vashishtha, 2012; Efendi, Srivastava, \& Swanson, 2007; Genus \& Coles, 2006; Gormley, Matsa, \& Milbourn, 2013; Hayes, Lemmon, \& Qiu, 2012). Frank and Goyal (2007) investigated that there are other members of top management team who are running the business and not only the CEO.

The second variable is stock liquidity and according to benchmark equation it shows that the adjusted $\mathrm{R}^{2}$ is 0.060 and after incorporating the CEO in benchmark equation the adjusted $\mathrm{R}^{2}$ increased with 0.136 and then we incorporate the CFO which gives significant change in adjusted $\mathrm{R}^{2}$ by 0.401 but in case of others the adjusted $\mathrm{R}^{2}$ decreased by 0.172 which means only CEO and CFO influence the stock liquidity and other top management doesn't influence. If we see the results of India, we can see that there is incremental change in adjusted $\mathrm{R}^{2}$ from the benchmark equation. After incorporating the CEO in the equation, the adjusted $R^{2}$ increased by 0.627 and same is the case for CFO the adjusted $R^{2}$ increased by 0.638 . But we also see that individually others are not influencing in stock liquidity decision, but they are jointly significant when we added them up in equation. The results of Brazil are same as India and China. After incorporating CEO and CFO the $F$-statistics and $p$-value shows significant influence on decision of the stock liquidity but other are showing insignificant impact on stock decisions. The results of Russia and South Africa shows that only CFO influence the decisions of stock liquidity while when we incorporated the CEO and others in benchmark equation the adjusted $\mathrm{R}^{2}$ decreased as mentioned in Table 2 . According to Chan and Faff (2005) they concluded in their study that emerging markets have shown mixed results with respect to stock liquidity. However, it has been proven by empirical evidence that liquidity have great 
importance for emerging market (Bekaert, Harvey, \& Lundblad, 2007; Lee, 2011). Another study confirmed that determinants of risk may vary for developed and emerging markets. However, Lang, Lins, and Maffett (2012) articulated that emerging markets have higher transactional cost and lower liquidity for the firms. Hence the increase in growth of emerging markets in past few years will increase the popularity among investors (Kang \& Zhang, 2014). Y. Chen et al. (2015) investigated in their study that top managers prefer to do short term earning management at the cost of long-term growth to attain the higher stock price. Dichev, Graham, Harvey, and Rajgopal (2013) investigated that many companies are prone to do earnings in order to influence the stock price, so greater the stock liquidity greater the pressure on managers from the capital market to take short term decisions.

\section{Observable Managerial Characteristics}

The previous section of the study tells us that managers do impact the decision making of the firm, but the presence of managerial financial styles doesn't explain that which characteristic of managers influence more in the decision making. For this we take age, gender, experience and qualification ${ }^{3}$ as observable characteristics of manager which can influence the financial decisions such as stock liquidity and firms' risk. According to Bertrand and Schoar (2003), age can be a relevant managerial characteristic because normally it is proposed that older managers are more conservative in decision making. In the results interpreted in Table 3, there are number of studies which confirmed that manager characteristics do have influence on financial decision making of firm. The results can be interpreted with the signs of the coefficient of each characteristic and they can be construed as conservative or aggressive. Like managers above 50 years of age are less likely to take risk (conservative) that's why our coefficient depicts negative sign. Whereas, younger top managers are willing to take more risks because they want a higher growth for their firm (Eaton \& Rosen, 1983). On the other hand, if the top managers are having MBA degree, they are less likely to take risk because they usually do different valuation techniques before taking any decisions. There are mixed results from the study some presented positive relationship with risk (Nadkarni and Herrmann 2010) and some concluded negative results (Chevalier \& Ellison, 1999; Graham et al., 2013). The results show that manager with higher tenure tends to take more risky decisions. According to Stein (1989) managers usually take short term decisions to maintain high stock liquidity and forgo the long-term decisions such as R\&D investment decisions (Xu \& Yan, 2014). Again, the experience of top manager has mixed results from the literature some said tenure have significant positive relationship with risk (Bloom \& Milkovich, 1998; M. Serfling, 2016) while others presented negative relationship (Chakraborty, Sheikh, \& Subramanian, 2007).

\section{Conclusion}

The objective of this study was to examine the role of top management team on decision making considering their observable and unobservable characteristics on firm risk and stock liquidity. To attain this objective, we have taken manager firm match panel data of non-financial listed firms of BRICS from 2010 to 2018 on their respective stock exchanges. Previous studies show that BRICS have become a challenging economic force globally by expanding trade with rest of the world. Even though the preceding literature provides enough evidence to support our argument that top managers have significant impact on the company's decision and performance (Kutan et al., 2018). In continuation of Kutan et al. (2018), Ling (2012) and Bertrand and Schoar (2003), our study contributed in three-fold, subject matter, economic and geographic context. It has been observed that most of the manager's characteristic studies have been conducted on developing and developed countries and very little attention was given to emerging economy which contributes to a major part of the world economy. The reason to choose BRICS is because all the countries are different in terms of financial structures, income level, technological advancement and political situations, so it is required to have different geographic and economic context in order to

${ }^{3}$ Graham and Harvey (2001) conclude in their study that CFOs having MBA qualification used more refined valuation techniques as compared to non-MBA. 
commend any financial and economic concept. Furthermore, the prevailing literature overlooked the manager financial styles on stock liquidity and firm risk (which is a limitation with respect to subject matter).

The results demonstrated that top managers of India, China and Brazil shows that the CEO and CFOs matter for firm risk and stock liquidity decisions whereas, South Africa and Russia shows that only CFO matter for the firm risk and stock liquidity decisions. Chan and Faff (2005) concluded in their study that emerging markets have shown mixed results with respect to stock liquidity. However, it has been proven by empirical evidence that liquidity have great importance for emerging market (Bekaert et al., 2007; Lee, 2011). According to (Bertrand \& Schoar, 2003), age can be relevant managerial characteristics because normally it is proposed that older managers are more conservative in their decision making. Whereas, younger top managers are willing to take more risks because they want higher growth for their firm (Eaton \& Rosen, 1983). On the other hand, if the top managers are having MBA degree then they are less likely to take risk because they usually perform diverse valuation techniques before taking any decision. The results show that manager with higher tenure tends to take more risky decisions.

According to Stein (1989) managers usually take short term decisions to maintain high stock liquidity and forgo the long-term decisions such as R\&D investment decisions (Xu \& Yan, 2014). Again, the experience of top managers has mixed results from the literature, few said tenure have significant positive relationship with risk (Bloom \& Milkovich, 1998; M. Serfling, 2016) while others presented negative relationship (Chevalier \& Ellison, 1999; Genus \& Coles, 2006). BRICS have significant influence on global and regional affairs because of their economic situation. Additionally, a study reveals that these five countries represent $40 \%$ of the world population and approximately covers $20 \%$ of the world GDP (Tripathi \& Kumar, 2014). South Africa has different economic conditions as compared to the other four countries. A study reveals that the country does not fulfil all the characteristics related to the country group. Firstly, a strong economy, secondly a strong growth rate and lastly strong political voice. However, besides the BRICS these five countries also form different alliances. This study supports the evidence of the existing literature that top management team influence the firm financial decision (such as firm risk and stock liquidity) which is supported by the upper echelon theory.

The investigation will be beneficial for the potential investors, the regulatory authorities and the academia. As the shareholders are the ones who invest a large amount of money in the shares and the regulatory authorities are the ones who devise strategies therefore, the study will assist them before taking any investment decision or developing strategy. Whereas, for academia the study will fill the gap in the current literature.

\section{Reference}

Acharya, V. V., \& Pedersen, L. H. (2005). Asset pricing with liquidity risk. Journal of financial Economics, 77(2), 375-410.

Ahmed, A., \& Ali, S. (2017). Boardroom gender diversity and stock liquidity: Evidence from Australia. Journal of Contemporary Accounting \& Economics, 13(2), 148-165.

Albuquerque, R., Koskinen, Y., \& Zhang, C. (2019). Corporate social responsibility and firm risk: Theory and empirical evidence. Management Science, 65(10), 4451-4469.

Amihud, Y. (2002). Illiquidity and stock returns: cross-section and time-series effects. Journal of financial markets, 5(1), 31-56.

Armstrong, C. S., Larcker, D. F., Ormazabal, G., \& Taylor, D. J. (2013). The relation between equity incentives and misreporting: The role of risk-taking incentives. Journal of financial Economics, 109(2), 327-350.

Armstrong, C. S., \& Vashishtha, R. (2012). Executive stock options, differential risk-taking incentives, and firm value. Journal of financial Economics, 104(1), 70-88. 
Beaudoin, C. A. (2008). Earnings management: The role of the agency problem and corporate social responsibility.

Bekaert, G., Harvey, C. R., \& Lundblad, C. (2007). Liquidity and expected returns: Lessons from emerging markets. The Review of Financial Studies, 20(6), 1783-1831.

Bernile, G., Bhagwat, V., \& Rau, P. R. (2017). What doesn't kill you will only make you more risk-loving: Early-life disasters and CEO behavior. The Journal of Finance, 72(1), 167-206.

Bertrand, M., \& Schoar, A. (2003). Managing with style: The effect of managers on firm policies. The Quarterly journal of economics, 118(4), 1169-1208.

Bloom, M., \& Milkovich, G. T. (1998). Relationships among risk, incentive pay, and organizational performance. Academy of Management Journal, 41(3), 283-297.

Bolton, P., Chen, H., \& Wang, N. (2011). A unified theory of Tobin's q, corporate investment, financing, and risk management. The Journal of Finance, 66(5), 1545-1578.

Booth, P., \& Schulz, A. K.-D. (2004). The impact of an ethical environment on managers' project evaluation judgments under agency problem conditions. Accounting, Organizations and Society, 29(56), 473-488.

Bruno, V., \& Shin, H. S. (2015). Cross-border banking and global liquidity. The Review of Economic Studies, 82(2), 535-564.

Cassell, C. A., Huang, S. X., Sanchez, J. M., \& Stuart, M. D. (2012). Seeking safety: The relation between CEO inside debt holdings and the riskiness of firm investment and financial policies. Journal of financial Economics, 103(3), 588-610.

Chakraborty, A., Sheikh, S., \& Subramanian, N. (2007). Termination risk and managerial risk taking. Journal of Corporate Finance, 13(1), 170-188.

Chan, H. W., \& Faff, R. W. (2005). Asset pricing and the illiquidity premium. Financial Review, 40(4), 429-458.

Chava, S., \& Purnanandam, A. (2007). Determinants of the floating-to-fixed rate debt structure of firms. Journal of financial Economics, 85(3), 755-786.

Chen, H. L., Ho, M. H. C., \& Hsu, W. T. (2013). Does board social capital influence chief executive officers' investment decisions in research and development? R\&D Management, 43(4), 381-393.

Chen, Y., Rhee, S. G., Veeraraghavan, M., \& Zolotoy, L. (2015). Stock liquidity and managerial shorttermism. Journal of Banking \& Finance, 60, 44-59.

Chernin, A. (2008). The effects of food marketing on children's preferences: testing the moderating roles of age and gender. The ANNALS of the American Academy of Political and Social Science, 615(1), 101118.

Chevalier, J., \& Ellison, G. (1999). Career concerns of mutual fund managers. The Quarterly journal of economics, 114(2), 389-432.

Chordia, T., Huh, S.-W., \& Subrahmanyam, A. (2009). Theory-based illiquidity and asset pricing. The Review of Financial Studies, 22(9), 3629-3668.

Chordia, T., Subrahmanyam, A., \& Anshuman, V. R. (2001). Trading activity and expected stock returns. Journal of financial Economics, 59(1), 3-32.

Cooper, S. K., Groth, J. C., \& Avera, W. E. (1985). Liquidity, exchange listing, and common stock performance. Journal of Economics and Business, 37(1), 19-33.

Copeland, T. E., Koller, T., \& Murrin, J. (2002). Unternehmenswert: Methoden und Strategien für eine wertorientierte Unternehmensführung: Campus Verlag.

Das, G. (2014). Impact of store image on store loyalty and purchase intention: does it vary across gender? International Journal of Electronic Marketing and Retailing, 6(1), 52-71.

Datar, V. T., Naik, N. Y., \& Radcliffe, R. (1998). Liquidity and stock returns: An alternative test. Journal of financial markets, 1(2), 203-219.

Dejong, D., \& Ling, Z. (2013). Managers: Their effects on accruals and firm policies. Journal of Business Finance \& Accounting, 40(1-2), 82-114.

Dichev, I. D., Graham, J. R., Harvey, C. R., \& Rajgopal, S. (2013). Earnings quality: Evidence from the field. Journal of Accounting and Economics, 56(2-3), 1-33. 
Dongwei, S., \& Yuanxun, M. (2004). Liquidity and Asset Pricing: An Empirical Exploration of Turnover and Expected Returns on Chinese Stock Markets [J]. Economic Research Journal, 2, 95-105.

Eaton, J., \& Rosen, H. S. (1983). Agency, delayed compensation, and the structure of executive remuneration. The Journal of Finance, 38(5), 1489-1505.

Edmans, A. (2009). Blockholder trading, market efficiency, and managerial myopia. The Journal of Finance, 64(6), 2481-2513.

Edmans, A., Fang, V. W., \& Zur, E. (2013). The effect of liquidity on governance. The Review of Financial Studies, 26(6), 1443-1482.

Efendi, J., Srivastava, A., \& Swanson, E. P. (2007). Why do corporate managers misstate financial statements? The role of option compensation and other factors. Journal of financial Economics, 85(3), 667-708.

Elsaid, E., \& Ursel, N. D. (2011a). CEO succession, gender and risk taking. Gender in Management: An International Journal, 26(7), 499-512.

Elsaid, E., \& Ursel, N. D. (2011b). CEO succession, gender and risk taking. Gender in Management: An International Journal.

Faccio, M., Marchica, M.-T., \& Mura, R. (2016). CEO gender, corporate risk-taking, and the efficiency of capital allocation. Journal of Corporate Finance, 39, 193-209.

Fang, V. W., Tian, X., \& Tice, S. (2014). Does stock liquidity enhance or impede firm innovation? The Journal of Finance, 69(5), 2085-2125.

Finkelstein, S., Hambrick, D., \& Cannella, A. A. (1996). Strategic leadership. St. Paul: West Educational Publishing.

Frank, M. Z., \& Goyal, V. K. (2007). Corporate leverage: How much do managers really matter? Available at SSRN 971082.

Genus, A., \& Coles, A.-M. (2006). Firm strategies for risk management in innovation. International Journal of Innovation Management, 10(02), 113-126.

Glosny, M. A. (2010). China and the BRICs: A real (but limited) partnership in a unipolar world. Polity, 42(1), 100-129.

Glover, B., \& Levine, O. (2015). Uncertainty, investment, and managerial incentives. Journal of Monetary Economics, 69, 121-137.

Goldman, E., Rocholl, J., \& So, J. (2009). Do politically connected boards affect firm value? The Review of Financial Studies, 22(6), 2331-2360.

Gormley, T. A., Matsa, D. A., \& Milbourn, T. (2013). CEO compensation and corporate risk: Evidence from a natural experiment. Journal of Accounting and Economics, 56(2-3), 79-101.

Graham, J. R., \& Harvey, C. R. (2001). The theory and practice of corporate finance: Evidence from the field. Journal of financial Economics, 60(2-3), 187-243.

Graham, J. R., Harvey, C. R., \& Puri, M. (2013). Managerial attitudes and corporate actions. Journal of financial Economics, 109(1), 103-121.

Gustafsson, P., \& Uysal, E. (2018). CEO? Or More Like RiskEO?: A Cross-Sectional Study of CEO Characteristics and Firm Risk-Taking.

Hambrick, D. C. (2007). Upper echelons theory: An update: Academy of Management Briarcliff Manor, NY 10510.

Hambrick, D. C., \& Mason, P. A. (1984). Upper echelons: The organization as a reflection of its top managers. Academy of management review, 9(2), 193-206.

Harrell, A., \& Harrison, P. (1994). An incentive to shirk, privately held information, and managers' project evaluation decisions. Accounting, Organizations and Society, 19(7), 569-577.

Harrison, P. D., \& Harrell, A. (1993). Impact of "adverse selection" on managers' project evaluation decisions. Academy of Management Journal, 36(3), 635-643.

Haugen, R. A., \& Baker, N. L. (1996). Commonality in the determinants of expected stock returns. Journal of financial Economics, 41(3), 401-439.

Hayes, R. M., Lemmon, M., \& Qiu, M. (2012). Stock options and managerial incentives for risk taking: Evidence from FAS 123R. Journal of financial Economics, 105(1), 174-190. 
Herrmann, P., \& Datta, D. K. (2005). Relationships between top management team characteristics and international diversification: An empirical investigation. British Journal of Management, 16(1), 69-78.

Hirshleifer, D., \& Thakor, A. V. (1992). Managerial conservatism, project choice, and debt. The Review of Financial Studies, 5(3), 437-470.

Jiang, F., Ma, Y., \& Shi, B. (2017). Stock liquidity and dividend payouts. Journal of Corporate finance, 42 , 295-314.

Kamara, A., Lou, X., \& Sadka, R. (2008). The divergence of liquidity commonality in the cross-section of stocks. Journal of financial Economics, 89(3), 444-466.

Kang, W., \& Zhang, H. (2014). Measuring liquidity in emerging markets. Pacific-Basin Finance Journal, 27, 49-71.

Khan, W. A., \& Baker, H. K. (1993). Unlisted trading privileges, liquidity, and stock returns. Journal of Financial Research, 16(3), 221-236.

Khan, W. A., \& Vieito, J. P. (2013). CEO gender and firm performance. Journal of Economics and Business, 67, 55-66.

Kini, O., \& Williams, R. (2012). Tournament incentives, firm risk, and corporate policies. Journal of financial Economics, 103(2), 350-376.

Kutan, A. M., Naz, I., \& Shah, S. M. A. (2018). Are top managers important for firm performance and idiosyncratic risk? Evidence from sharia vs non-sharia-compliant firms in the UK and Pakistan. The World Economy, 41(3), 763-780.

Lalthapersad-Pillay, P. (2014). Gender Influences in the Labour Market: The Case of BRICS. Mediterranean Journal of Social Sciences, 5(10), 146.

Lang, M., Lins, K. V., \& Maffett, M. (2012). Transparency, liquidity, and valuation: International evidence on when transparency matters most. Journal of Accounting Research, 50(3), 729-774.

Lee, K.-H. (2011). The world price of liquidity risk. Journal of financial Economics, 99(1), 136-161.

Marcelo, J. L. M., \& Quirós, M. d. M. M. (2006). The role of an illiquidity risk factor in asset pricing: Empirical evidence from the Spanish stock market. The Quarterly Review of Economics and Finance, 46(2), 254-267.

Meckling, W. H., \& Jensen, M. C. (1976). Theory of the firm: Managerial behavior, agency costs and ownership structure. Journal of financial Economics, 3(4), 305-360.

Paligorova, T., \& Santos, J. A. (2017). Monetary policy and bank risk-taking: Evidence from the corporate loan market. Journal of Financial Intermediation, 30, 35-49.

Pedro, D. M., Irene, K., Doris, K., \& Thobias, S. (2012). The Role of BRICS in the Developing World. Directorate General For External Policies of the Union.

Perryman, A. A., Fernando, G. D., \& Tripathy, A. (2016). Do gender differences persist? An examination of gender diversity on firm performance, risk, and executive compensation. Journal of Business Research, 69(2), 579-586.

Polk, C., \& Sapienza, P. (2008). The stock market and corporate investment: A test of catering theory. The Review of Financial Studies, 22(1), 187-217.

Rotemberg, J. J., \& Saloner, G. (2000). Visionaries, managers, and strategic direction. RAND Journal of Economics, 693-716.

Rouwenhorst, K. G. (1999). Local return factors and turnover in emerging stock markets. The Journal of Finance, 54(4), 1439-1464.

Rutledge, R. W., \& Karim, K. E. (1999). The influence of self-interest and ethical considerations on managers' evaluation judgments. Accounting, Organizations and Society, 24(2), 173-184.

Sappington, D. E. (1991). Incentives in principal-agent relationships. Journal of economic Perspectives, 5(2), 45-66.

Serfling, M. (2016). Firing costs and capital structure decisions. The Journal of Finance, 71(5), 2239-2286.

Serfling, M. A. (2014). CEO age and the riskiness of corporate policies. Journal of Corporate Finance, 25, 251-273.

Singh, H., \& Harianto, F. (1989). Management-board relationships, takeover risk, and the adoption of golden parachutes. Academy of Management Journal, 32(1), 7-24. 
Smith, M., \& White, M. C. (1987). Strategy, CEO specialization, and succession. Administrative Science Quarterly, 263-280.

Stein, J. C. (1989). Efficient capital markets, inefficient firms: A model of myopic corporate behavior. The Quarterly journal of economics, 104(4), 655-669.

Sundaram, R. K., \& Yermack, D. L. (2007). Pay me later: Inside debt and its role in managerial compensation. The Journal of Finance, 62(4), 1551-1588.

Thomas, A. S., Litschert, R. J., \& Ramaswamy, K. (1991). The performance impact of strategy-manager coalignment: An empirical examination. Strategic management journal, 12(7), 509-522.

Tihanyi, L., Ellstrand, A. E., Daily, C. M., \& Dalton, D. R. (2000). Composition of the top management team and firm international diversification. Journal of management, 26(6), 1157-1177.

Tripathi, V., \& Kumar, A. (2014). Relationship between Inflation and stock returns-evidence from BRICS markets using Panel Co integration Test. International Journal of Accounting and financial reporting, 4(2), 647-658.

Tuttle, B., Harrell, A., \& Harrison, P. (1997). Moral hazard, ethical considerations, and the decision to implement an information system. Journal of Management Information Systems, 13(4), 7-27.

Van den Steen, E. (2004). Rational overoptimism (and other biases). American Economic Review, 94(4), 1141-1151.

Vroom, V. H., \& Pahl, B. (1971). Relationship between age and risk taking among managers. Journal of applied psychology, 55(5), 399.

Weintraub, E. R. (2007). Neoclassical Economics. The Concise Encyclopedia Of Economics. Retrieved September 26, 2010.

Wiersema, M. F., \& Bantel, K. A. (1992). Top management team demography and corporate strategic change. Academy of Management journal, 35(1), 91-121.

Xiong, J. (2016). Stock Liquidity and Firm Investment-Evidence from Chinese Listed Companies. Journal of Business Theory and Practice, 4(1), 2329-2644.

$\mathrm{Xu}, \mathrm{C} .$, \& Yan, M. (2014). Radical or incremental innovations: R\&D investment around CEO retirement. Journal of Accounting, Auditing \& Finance, 29(4), 547-576. 